DOI: $10.17516 / 1997-1370-0650$

УДК 1(091)

\title{
Rational Theology in Polemic Strategies of Early Christian Apologues
}

\author{
Roman V. Svetlova and Dmitry V. Shmonin ${ }^{\mathrm{a}, \mathrm{b}, \mathrm{c}}$ \\ anstitute of Human Philosophy \\ Herzen State Pedagogical University of Russia \\ St. Petersburg, Russian Federation \\ ${ }^{b}$ Saints Cyril and Methodius Institute for Postgraduate Studies \\ Moscow, Russian Federation \\ ${ }^{c} U N E S C O$ Chair on theory of education \\ Herzen State Pedagogical University of Russia \\ St. Petersburg, Russian Federation
}

Received 06.07.2020, received in revised form 05.08.2020, accepted 10.08.2020

\begin{abstract}
The texts of early Christian apologists are an example of a clear argumentative reaction to a number of external and internal challenges. The internal ones included changes in the size and structure of the community, increased heterodoxia, and a decrease in eschatological moods. Among the external - on the one hand, the growth of hostility and systematic persecution on the part of Rome, on the other, the specific atmosphere of the "age of the Antonines", age of imperators who practiced, at least formally, a policy of mercy. All this stimulated the development of rhetoric in Christian literature, the formation of the genre of Christian apology, as well as specific apologetic strategies, in which early Christian rational theology was reflected. Its most important element was the formation of ideas about a righteous life as the root condition of philosophical wisdom. It is this approach that helps, for example, Justin Martyr find a way to convert ancient wisdom into a rational-theological toolkit of apologetics.
\end{abstract}

Keywords: Socrates, Justin the Martyr, rational theology, cultural conflict in the Roman Empire.

The reported study was funded by RFBR according to the research project no. 18-0000727 (18-00-00628).

Research area: theology; history of philosophy.

Citation: Svetlov, R.V., Shmonin, D.V. (2020). Rational theology in polemic strategies of early Christian apologues. J. Sib. Fed. Univ. Humanit. Soc. Sci., 13(8), 1398-1404. DOI: 10.17516/1997-1370-0650.

\footnotetext{
(C) Siberian Federal University. All rights reserved

* Corresponding author E-mail address: spatha@mail.ru, dmitry.shmonin@gmail.com ORCID: 0000-0001-7767-1441 (Svetlov); 0000-0002-5396-0027 (Shmonin)
} 
The teachings of rational theology (theologia rationalis) were commonly thought to be developed when rational procedures were applied to simple, basic truths (revelabile). In Christian scholastics such a layer of rational-religious knowledge was known as natural or philosophical theology. However, the term ration theology was also applied to truths, given in Revelation (revelatum), which did not apply to the mystical experiences of divine communion in Christian life but described how mysticism takes root in theology.

Currently, rational theology is being talked about as the correct descriptor for systems of religious teaching in traditional Christian confessions, from their origins and to church-confessional specifics (Shmonin, 2019). In some way, one can even speak about the origins of rational theology in ancient religious mindsets. Using this understanding of rational theology, one can also talk about Jewish and Islamic theology; pursuing these possibilities they should be used correctly in the context of united worldviews in modern theological science. Religious teaching about law and rights in Judaism and Islam contain similar to Christianity Abrahamic roots, wherein are contained the stories about the divine creation of the world, man, eternal values and non-theological knowledge - including those in the organized three dimensional space of scientific rationality.

At the injunction of the middle ages and modern times, within the tenants of classical science, the term "theologia rationalis" received new connotations (Vdovina, 2007). Francisco Suárez, for example perceives rational theology as an attempt to view God through the mind's eye and the world created by him, not only in the basic interpretation but also in the moral-ethical one. In short, that is precisely the difference between rational theology and metaphysics: they align on topics but theology has a higher goal and while metaphysics might carry only a theoretical character, theology exists in the realms of both the practical and the mind's eye. Both dimensions are important to Christianity, although practical theology in catholic tradition often ends up beyond the framework of knowledge and education.
We have already examined the topic of rational theology with several historical examples. From a historical perspective, discussions, which attempt to "rationalize" religious truths, adapting them to the realities and arguments that prevail in education, science and consciousness of the time period, are particularly prevalent in three separate situations. We will remark here that these situations vary by their cause as well as their consequences.

The first - the altering of the intellectual horizon, making it no longer conform to the traditional religions world view (Svetlov, 2019). The second - an encounter with a radically different religious tradition (Svetlov, 2020). And the third - the birth of a fundamentally different religious truth, as it occurred in the case of Christianity. This is precisely the scenario that we wish to examine in the following paper.

We shall remark first that rational theology among apologues of the II and III centuries was not an intellectual goal in of itself. Everything was a lot more serious, since its formation was directly tied to the fate the Christian community. In the following paper we aim exactly to study this, 'functional' side of the problem.

Let us begin with a rather weighty topic. The project of Philo of Alexandria had the goal of translating the philosophical language of the Hellenistic period and the language of the Revelation of Old Testament. A translation which have placed the history of Israel into the universality of the Hellenistic history but did not end up achieving the author's desired results. The roman-jewish conflicts of the I and II centuries have ended any attempts at such syncretic interpretations of the Old Testament in the context of Judaism and have led to a negative reception of the Septuagint in Jewish culture. Some Christian authors, especially from the Alexandria, took positively to the ideas expressed in Philo's project, but ended up interpreting it through their own views. Philo was important for them because he was propped up as an example that one could talk about the scriptures not only in the norms of tradition but also in the norms of "scientific" thought, which at the time, was mainly found in ancient philosophy. 
Why did the apologues need these norms? We believe, that the need for them can be explained by the various obstacles that Christian communities have encountered during the earliest periods of its history. This multifaceted situation must be taken into account if we are to talk about how Christianity transforms from "barbaric wisdom" (Tatianus), that was put in opposition to the Hellenic teachings to "true philosophy" (Clement of Alexandria), that claims that it has embraced everything good that was created since the times of Moses and transcends "both the Hebrew and the Hellenic".

The challenges were connected to the outer historical, political and cultural circumstances, as well as the inner histories of early Christian communities that had gone through a whole host of upheavals. Let us try to characterize them.

The most important upheavals occurred naturally within the church itself. The pertain to the growth of its membership, exceeding the Hebrew and Hellenic "heterotoxy", the refusal to compromise with "faith of the parents", along with attempts to centralize various Judeo-Christian movements and, in some cases, attempts to fully separate from the Old Testament (of Marcion). Proselytization of the Christian dogma, with all its benefits, could also lead to the watering down of New Testament Christian dogma.

The second important factor was the lessening of eschatological expectation in Christian communities in the II century. The logic is obvious - waiting for the inevitable and soonto-come end of the world makes a religious community quite desensitized to anything happening in the world around it. It can swing either to radical piety, concerned only with the greatest possible sainthood of its members or to calls to radically remake society, which would otherwise be left without hope for salvation. Either options will put a religious community in conflict with its surrounding (for this reason, modern religious studies dub such communities "dualistic" - not so much because of what is contained in their teachings but because of complete rejection of anything that is outside of the community). In the II century we can see a whole host of attempts to create such du- alistic groups within the confines of Christianity - from sects of gnostic interpretation to Montanism. We understand how much the contents of gnostic gospels and concept of Montan (who we know very little about) differed from each other, however, one and the other both cut Christendom from its surrounding culture, the social and political realities, foremost due to their high eschatology.

The criticism of actually knowing when the end of the world will arrive was already a contentious religious topic. But even without it, the degree of eschatologicality was decreasing (but it should be noted that during the middle ages there would be waves of anticipation of the Second Advent - especially during societal or natural calamities). And this means that the church needs to define the goals of its societal programs and have a clear understanding of what the Scriptures say about them.

The third factor - heterodoxy, which arose within communities that called themselves Christian at the very beginning of their history. If a generation of apostles was chiefly concerned with movements such as the so called nicolaism, then already by the end of the I century, the amount of "Gnostic" sects was rapidly increasing. Without delving into the question about how much one can talk about gnosticism as a conceptually whole phenomenon, we will nevertheless draw attention to the fact that early Christian texts contained a lot of metaphors that resembled that of gnosticism. It is enough to read "Haermae Pastor", to see the allegorical forms in need of specialized "knowing" interpreting. The border with Gnostic apocalypse seems rather thin and while the author of "Haermae Pastor" does not cross it, it is obvious that early Christians viewed themselves not just as keepers of new knowledge but also those living on the edge between this world and the realm of God. Gnosticism exploited these perception, adding to the norms prescribed in the New Testament, the prelude of genesis (the "Gnostic myth"), as well as an expended sum of esoteric knowledge about Pleroma (true reality) and ways of achieving it (through a special intellectual and ritualistic communion). This "esoteric" variant of Christianity was, without question, adogmatic and adoctrinal. Added to 
this was the fact that every community had its own procedures for obtaining gnosis, which caused a great amount of headache for future Christian Heresiologists when they tried to describe gnostic views.

For brevity we will skip a part of questions, which also were of concern to Christian communities (for example, the date of Easter) and let us transition to outer circumstances, which required the apologues to react.

The growth of the Christian community naturally provoked concerns from the roman government. If the story about the conversation between Domitian and the descendants of the family of Jesus Christ could be a late fiction (Euseb. Hist. Eccl. III, 20), the emperor Trajan was obvious set to implement harsher limiting measures towards Christianity and during his rule we can see attempts to formulate arguments to depropogandize then leaders of Christian communities (Plin. Ep. Tra. X.96. 2-3). A contentious situation arises. On one end, Christianity does not participate in a battle against the Roman government - compared to Judaism - but is unable to find its own place in the structure of the Roman government, a problem that carried a fundamental character. It pertains not only to the distrusts of the pagans to this new knowledge but also the refusal of Christians to cooperate with the government on various important topics: religious burials, which would have shown their loyalty to the ruling class, as well as take an oath to the emperor as one's lord and (in the case of soldiers).

Because of this, the dynasty of Antonine, which had been in power for almost the entirety of the II century, a dynasty which espoused the tenants of mercy (Misericordia, Clementia) that had once been a pragmatic part of Cesar's politics (Ahiev, 2002) and later sung by Seneca as one of the chief goods of ruler (Sen. De Clem. I. 11. 4), continued to pursue Christians, while notably distinguishing between them and Judaists. However, the prestige of carrying the titles of "philosopher kings", which was more or less consciously supported by a part of Antonines, created the possibility of having a polemic conversation with them. After all, the most respected philosopher at the time, Socrates, has claimed that the greatest measure of wisdom is the ability to have a conversation. But, naturally, to have a conversation with the emperor himself one needs a truly extraordinary situation. Such has been court, which in principle, allowed for various mediations. From the descriptions of court procedures from early Christian sources we can see that they often employed methods of early ancient rhetoric, both in word and in gesture (Panteleev, 2018).

Another example of this rhetoric became "Apologues", which were created by early Christian writers. Similar to the earliest court defense - the defense of Socrates in 399 BCE, apologues demonstrate their philosophical education and cultural prowess, putting themselves as equals to ancient "martyrs" of philosophy. The famous pallium ("tribon") of Justin Martyr was a symbol of this - the closeness in spirit to the wise men of the past who suffered at the hands of corrupt governments and unenlightened mobs.

The typology of Christian apologues, ways of argumentation, that were used there - that is a separate question, that has been studied by researchers more than once (Vdovichenko, 2000: 24-38). It is clear, that the subjects of several of apologues could likely not know about their existence (especially when talking about the very heights of power - Hadrianus, Antoninus Pius, Marcus Aurelius). Christianity at the time was viewed by the ruling class, to use modern terms, a totalitarian sect and its texts were not given any polemical or theoretical importance (we can even see this type of attitude towards Christianity from followers of Neoplatonism of the Athenian school, who lived in the age Christian dominance). Because of this, the ability to communicate with the ruling class of the Antonines with their specific propaganda and ideology, was naturally, very indirect but still happened as part of that Zeitgeist.

In the end, however, it seems that the true receiver of the apologues would be the Christian communities themselves - already mature enough to receive philosophical arguments and be swayed historical precedents. An indirect proof of this is the polemic writings against the jews of the II centuries - "Dialogue of Jason and Papiscus" (Ariston of Pella) and "Dialogue with Trypho" (Justin). They were obvious- 
ly written for the wider christian community, many of which could be swayed toward Judeo-Christianity or outright Judaism (especially during a time in which judais, while severely restricted, still had a legal place within the Roman empire, while Christianity remained in limbo). The apologues were also targeted at pagans, becoming a way to deliver information about the most important moments of Christian doctrine, giving further validation to the truthfulness of the new faith.

Polemic battles against the enemies of Christianity led to the creation of the Christian holy speech, which did not match that of the Scriptures but was also not a repeat of the language of ancient philosophy and science, which were normally used by Christian writers (Edwards 1999). We should remark, that some of them (Justin, Clement of Alexandria, Origen) have directly led to the formation and development of Christian educational institutions "didascalias" (in Rome and Alexandria). "Stromata" of Clement of Alexandria and "De principiis" of Origen have shown, the breadth of topics, that was studied there, as well as philosophical concepts, which transferred from Platonism and Stoicism but changed their tone and roles among Christian authors (Drog, 1987; Young, 1989).

While arguing with pagans and Judaists, the apologues began dictating the normative side of Christian doctrine, which created the conditions for battling heterodoxy and developing the criteria for what, from then on, will be known as heresy. The slow dim of eschatological expectations was expressed by the apologues stimulation of the formation of a system of arguments through which the wider roman society could be evangelized. As such, early Christian apologian literature became the narrative that became vital to constructing the united church - both in social as well as discursive levels, since the adaptation of discursive norms leads to the adaptation of social responsibilities. Rational theology played a huge role in consolidating the Church and forming its political and social strategies. And the reaction of the original apologues to the upheavals, from a historical point of view, can be deemed a successful one.
To confirm our thesis on Apologues not being a replication of Hellenic philosophy, but rather connected to an entirely different religious system and, because of this, a whole other form of discourse, we shall provide just one example.

The Apologies of Justin were the first examples where philosophical terminology was used in order to solve theological problems as [art of studying the nature of God. The differences between the positions of the philosopher and the preacher are elucidated in the already mentioned "Dialogue with Trypho", where discussions about how philosophers could speak and thing correctly about god, if they have no practical knowledge of him, ends with the thought that philosophical knowledge needs to be supplemented by knowledge of the prophets, who "only spoke that, which they saw and heard, while being vessels for the Holy Spirit". To the rational philosopher will be opened additional opportunities through theological rationality. These opportunities are given to a man in response to his faith, since rational theology can't exist without revelations, without the "prayer, that opens the pathway to light": for "such things are incomprehensible to all if God and Christ do not enlighten".

Justin the Martyr looked at Socrates (as well as Heracles) in precisely this context, as a "Christian before Christ" (Apol. I. 46) (Franek, 2016). In the opinion of the Christian apologue, Socrates was righteous (lived in accordance to logos), because precisely such a life coincides with wisdom. As Hebrew prophets were often maligned, so was Socrates at the hands of corrupt governments. To Justin Logos, which Socrates "partially glimpsed", is Jesus Christ himself (Apol. II. 10). Naturally, "historical" Socrates (the Socrates from the texts of Plato and Xenophon) talks about logos in a different meaning. For him it is a way of thinking, which allows someone to be freed from the "power of opinions" and to build their life by applying "second navigation" - using grasped values and meanings, critically analyzing everything. For an apologue, the rational side of the Logos is important but far more important is the understanding of Logos as a divine personality, which has been guiding people even before its 
coming into the world. Because of this, for Justin a life lived with Logos means a life lived in accordance to moral codes, proclaimed in the Sermon on the Mount but also known to wise men of the past. In the view of Justin, philosophical knowledge needs to be supported by the knowledge of prophets. When this condition is fulfilled, only then does philosophy can become an effective instrument in the hands of a preacher. "The people that are truly virtuous and wise need to love and respect only the truth..." (Apol. I. 2) - he writes, and then provides the thoughts of Plato, that if rulers ceased to engage in philosophy, there will not be prosperity in their states (Pl. Resp. $473 \mathrm{~d}$-e).

In this context, Justin simultaneously agrees with the Socrato-Platonic thesis, that "virtue is knowledge". But also understands it differently: Socrates "historically" achieves knowledge by himself (references to daimonion or the prophetess Diotima can be understood as metaphors for rational discourse), and this achievement because the pretense for his vir- tue (let us recall the famous Cicero's anecdote about the physiognomist Zopir, where Socrates says that philosophy has reeducated him - Cic. Tusc. IV, 37 (80)). The Socrates of Justin lives in accordance to the Logos of Revelation, and agreement is the logical pretense to virtue and wisdom. While Justin does not say when exactly Socrates converts but for him this conversion does not have a rational character, instead a spiritual one.

This is precisely the interpretation of Socrates (whit which some apologues disagreed with - ex. Tatianus "Oratio ad graecos") that lets Justin's convert ancient wisdom into rational-theological instruments of the apologues. This effort of Justin is supported by the thinkers of Alexandria who found themselves in a peculiar cultural situation within their city - the most important cultural center of the Hellenic epoch. This is why Alexandria can probably be viewed as the place where the matured form of Christian rational theology was developed but that is another topic.

\section{References}

Edwards, M.J. (1999). Justin's Logos and Word of God. In Christianity in relation to Jews, Greeks, and Romans. New York: Garland Publishing. P. 85-104.

Drog, A.J. (1987). Justin Martyr and the Restoration of Philosophy. In Church History, 56, 3 (Sep., 1987), 303-319.

Franek, J. (2016). Omnibus Omnia: The Reception of Socrates in Ante-Nicene Christian Literature. In Graeco-Latina Brunensia, 21, (1), 31-58.

Young, M.O. (1989). Justin, Socrates and the Middle-Platonists. In Studia Patristica, 18(2), 161-166.

Ahiev, S.N. (2002). Clementia Caesaris: sushchnost, prichiny, tseli [Clementia Caesaris: essence, reasons, goals]. In Ancient world and archeology, 11, 71-80.

Panteleev, A.D. (2018). "Muchenichestvo Apolloniya": ritoricheskiye strategii khristianina i sudi [The Martyrdom of Apollonius: the Christian's and the Judge's rhetorical strategies]. In Mnemon, 18, 2, 201-214.

Shmonin, D.V. (2019). Nauchnaya ratsionalnost i "vozvrashcheniye k teologii" [Scientific rationality and "reduction to the theology"]. In Issues of Theology, 1, 3, 280-306.

Svetlov, R.V. (2020). Ratsionalnaya teologiya: kazus Filona Aleksandriyskogo [Rational Theology: the case of Philo of Alexandria]. In Issues of Theology, 2, 1, 65-74.

Svetlov, R.V. (2019). Ratsionalnaya teologiya v antichnosti [Rational theology in antiquity]. In Proceedings of the Department of Theology of the St. Petersburg Theological Academy, 1 (3), 7-16.

Vdovichenko A. V. (2000) Khristianskaya apologiya. Kratkiy obzor traditsii [Christian apology. Tradition at a glance] In: Early Christian apologists of the 2nd-4th centuries. Moscow, P. 5-38.

Vdovina G. V. (2007) Estestvennaya teologiya v skholastike srednevekovia i rannego novogo vremeni [Natural Theology in Medieval and Early Modern Scholasticism]. In: Philosophy of Religion. Almanac. 2006-2007, P. 300-311. 


\title{
Рациональная теология в полемических стратегиях раннехристианских апологетов
}

\author{
Р.В. Светлов \\ ${ }^{a}$ Институт философии человека \\ Российский государственный педагогический \\ университет им. А.И. Гериена \\ Российская Федерачия, Санкт-Петербург \\ ${ }^{6}$ Общечерковная аспирантура и докторантура \\ имени святых равноапостольных Кирилла и Мефодия \\ Российская Федераџия, Москва \\ ${ }^{8}$ Кафедра ЮНЕСКО «Образование в поликультурном обществе» \\ Российский государственный педагогический \\ университет им. А.И. Гериена \\ Российская Федерация, Санкт-Петербург
}

\begin{abstract}
Аннотация. Творчество раннехристианских апологетов представляет собой пример четкой реакции на целый ряд внешних и внутренних вызовов. К числу внутренних относилось изменение численности и структуры общины, усиление гетеродоксии, снижение эсхатологических настроений. К числу внешних - с одной стороны, рост враждебности и систематического преследования Рима, с другой - особая атмосфера «века Антонинов», практиковавших хотя бы формально политику милосердия. Все перечисленное стимулировало развитие риторики в христианской литературе, формирование жанра христианской апологии, а также специфических апологетических стратегий, в которых получила отражение раннехристианская рациональная теология. Важнейшим ее элементом стало формирование представлений о жизни праведной как корневом условии философской мудрости. Именно такой подход помогает, например, Иустину найти способ конвертации античной мудрости в рационально-теологический инструментарий апологетики.
\end{abstract}

Ключевые слова: Сократ, Иустин Мученик, рациональная теология, культурный конфликт в Римской империи.

Исследование выполнено при финансовой поддержке РФФИ в рамках научного проекта № 18-00-00727 (18-00-00628).

Научные специальности: 26.00.00 - теология; 09.00.03 - история философии. 